\title{
SERANGGA-SERANGGA YANG BERASOSIASI PADA PERSEMAIAN PADI SAWAH DI KECAMATAN KOTAMOBAGU TIMUR KABUPATEN BOLAANG MONGONDOW
}

\section{INSECTS ASSOCIATED IN RICE NURSERY FIELDS IN EAST KOTAMOBAGU SUB DISTRICT, BOLAANG MONGONDOW REGENCY}

\author{
Irma S. Tunggali1), Juliet M. E. Mamahit2), dan Moulwy F. Dien) \\ 1)Almuni Fakultas Pertanian Unsrat manado \\ 2)Fakultas Pertanian, Universitas Sam Ratulangi Manado \\ 3)Perhimpunan Entomologi Indonesia (PEI), Cabang Manado
}

\begin{abstract}
This study aims to determine the types of insects that are associated to the rice nursery at sub district of East Kotamobagu, Bolaang Mongondow Regency. Research using Survey Methods on two sample locations at sub-district of East Kotamobagu, those are Kobo Besar and Kobo Kecil Village. Each location has determined by three specified locations in paddy rice nursery which is used as a sampling point. Sampling was done by using a sweep net by sweeping a double swing in ten times with the interval once a week for one month. The results showed that, there were ten species of insects associated in paddy rice nursery at sub-district of East Kotamobagu. Insects, has found were the order of Coleoptera, Orthoptera, Diptera, Odonata, Homoptera, and Hymenoptera. The identification of insects found in the areas of rice nurseries were: Nephotettis sp., Nilaparvata sp., Conocephalus sp., Oxya sp., Ophionea sp., Verania sp., Menochilus sp., Atherigona sp., Agriocnemis spp. and Ichneumonidae. From ten species of insects found four types of pests which act as Nephotettis sp., Nilaparvata sp., Oxya sp., and Atherigona spp.; five types act as a predator, those are: Conocephalus sp., Ophionea sp., Verania sp., Menochilus sp., Agriocnemis spp.; and one type of role as parasitoids, is family Ichneumonidae.
\end{abstract}

Keywords: rice nurseries field, insects

\begin{abstract}
ABSTRAK
Penelitian ini bertujuan untuk mengetahui jenis-jenis serangga yang berasosiasi pada persemaian padi sawah di Kecamatan Kotamobagu Timur, Kabupaten Bolaang Mongondow. Penelitian menggunakan metode survey pada dua lokasi sampel di Kecamatan Kotamobagu Timur, yaitu Desa Kobo Besar dan Kobo Kecil. Masing-masing lokasi ditentukan tiga persemaian padi sawah yang digunakan sebagai tempat pengambilan sampel. Pengambilan sampel dilakukan dengan menggunakan jaring serangga dengan cara penyapuan sebanyak sepuluh kali ayunan ganda dengan interval waktu seminggu sekali selama 1 bulan. Hasil penelitian menunjukkan bahwa, terdapat sepuluh jenis serangga yang berasosiasi pada persemaian padi sawah di Kecamatan Kotamobagu Timur. Serangga-serangga yang ditemukan adalah ordo Coleoptera, Orthoptera, Diptera, Odonata, Homoptera, dan Hymenoptera. Hasil identifikasi menunjukkan bahwa serangga-serangga yang ditemukan pada areal persemaian padi adalah Nephotettis sp., Nilaparvata sp., Conocephalus sp., Oxya sp., Ophionea sp., Verania sp., Menochilus sp., Atherigona sp., Agriocnemis spp. dan Ichneumonidae. Dari sepuluh jenis serangga yang ditemukan empat jenis berperan sebagai hama yaitu Nephotettis sp., Nilaparvata sp., Oxya sp., dan Atherigona spp.; lima jenis berperan sebagai predator yaitu Conocephalus sp., Ophionea sp., Verania sp., Menochilus sp., Agriocnemis spp. dan 1 jenis berperan sebagai parasitoid yaitu family Ichneumonidae.
\end{abstract}

Kata kunci : persemaian padi sawah, serangga

Eugenia Volume 19 No. 1 April 2013 


\section{PENDAHULUAN}

Padi merupakan bahan makanan yang menghasilkan beras. Bahan makanan ini merupakan makanan pokok bagi sebagian besar penduduk Indonesia. Meskipun padi dapat digantikan oleh makanan lainnya, namun padi memiliki nilai tersendiri bagi orang yang biasa makan nasi dan tidak dapat dengan mudah digantikan oleh bahan makanan yang lain (Anonim, 2004).

Tanaman padi dapat hidup baik di daerah yang berhawa panas dan banyak mengandung uap air. Curah hujan yang baik rata-rata $200 \mathrm{~mm}$ per bulan atau lebih, dengan distribusi selama 4 bulan, curah hujan yang dikehendaki per tahun sekitar 1500-2000 mm. Suhu rata-rata yang baik untuk pertumbuhan tanaman padi $23^{\circ} \mathrm{C}$. Tinggi tempat yang cocok untuk tanaman padi berkisar 0-1500 m dpl. Tanah yang baik untuk pertumbuhan tanaman padi adalah tanah sawah yang kandungan fraksi pasir, debu dan lempung dalam perbandingan tertentu serta diperlukan air dalam jurnlah yang cukup. Padi dapat tumbuh dengan baik pada tanah yang ketebalan lapisan atasnya antara $18-22 \mathrm{~cm}$ dengan pH antara 4 -7 (Anonim, 2007).

Teknik bercocok tanam yang baik sangat diperlukan untuk mendapatkan hasil yang sesuai dengan harapan. Hal ini harus dimulai dari awal, yaitu sejak dilakukan persemaian sampai tanaman tersebut bisa dipanen. Dalam proses pertumbuhan tanaman hingga berbuah ini harus dipelihara yang baik, terutama harus diusahakan agar tanaman terhindar dari serangan hama dan penyakit yang sering kali menurunkan produksi.

Dalam kehidupan sehari-hari karbohidrat merupakan salah satu zat yang sangat penting bagi tubuh dan sangat mutlak diperlukan setiap hari. Karbohidrat merupakan senyawa organik karbon, hidrogen, dan oksigen, yang terdiri atas satu molekul gula sederhana atau lebih yang merupakan bahan makanan penting sebagai sumber energi atau tenaga. Karbohidrat kita peroleh dari makanan pokok sehari-hari seperti padi, jagung, ketela pohon, kentang, sagu, gandum, ubi jalar dan lainlain. Dari sekian banyak sumber karbohidrat, padi ternyata merupakan ideal bagi kita. Itulah sebabnya padi menjadi komoditas unggul dan makanan pokok yang sangat penting bagi bangsa Indonesia.

Kabupaten Bolaang Mongondow merupakan salah satu daerah penghasil beras terbesar di Provinsi Sulawesi Utara. Penanaman padi di Provinsi Sulawesi Utara terpusat di berbagai kabupaten yakni di Kab. Bolaang Mongondow, Minahasa, Minahasa Selatan dan Minahasa Utara. Luas panen padi per tahun adalah 94,717 ha dari luas lahan baku 38,623 ha dengan produksi ratarata $48.03 \mathrm{kw} / \mathrm{ha}$, sehingga produksi total adalah 454,902 ton.

Di Kabupaten Bolaang Mongondow jenis padi yang banyak dibudidayakan adalah varietas serayu, sultan, dan super-win. Semua jenis padi lokal Indonesia harus dilestarikan dan dikembangkan agar terus bermanfaat bagi kehidupan Bangsa Indonesia dalam memenuhi kebutuhan hidup maupun kelestarian plasma nutfahnya Keberlanjutan produktivitas lahan sawah di Indonesia termasuk di Bolaang Mongondow menghadapi berbagai tantangan, diantaranya adalah rendahnya kandungan bahan organik tanah, dan terbatasnya ketersediaan air, terutama pada musim kemarau dan adanya serangan hama dan penyakit tumbuhan.

Upaya peningkatan produksi padi secara Nasional sudah dimulai sejak 1969 melalui program Bimas Gotong Royong, dengan menerapkan teknologi panca usaha secara persial berupa varietas unggul IR5 dan IR8, pemupukan, dan penyemprotan hama dari udara

Sampai saat ini hama masih menjadi kendala bagi petani. Hampir disetiap musim terjadi ledakan hama pada pertanaman padi. Hama utama tanaman padi antara lain adalah tikus, penggerek batang padi, dan wereng coklat. Beberapa hama lainnya yang berpotensi merusak pertanaman padi adalah wereng punggung puth, wereng hijau, lembuig batu, ulat grayak, pelipat daun, dan walangg sangit. Serangan hama tikus di Indonesia mencapai puncaknya pada tahun 1988, dengan luas serangan 159.000 ha dan intensitas serangan $24,8 \%$ penggerek batang merupakan serangan hama yang terdapat pada semua ekosistem padi dan menyerang tanaman sejak di persemaian hingga pertanaman. 
Melihat pentingnya hama sebagai faktor pembatas produktifitas padi, maka perlu dilakukan penelitian untuk mengetahui keanekaragaman serangga pada persemaian padi sawah di Kecamatan Kotamobagu Timur, Kabupaten Bolaang Mongondow.

Penelitian bertujuan untuk mengetahui jenis-jenis serangga yang berasosiasi pada persemaian padi sawah di Kecamatan Kotamobagu Timur, Kabupaten Bolaang Mongondow.

\section{METODE PENELITIAN}

Penelitian ini dilaksanakan di Kecamatan Kotamobagu Timur, Kabupaten Bolaang Mongondow dan di Laboratorium Hama dan Penyakit Tumbuhan, Fakultas Pertanian Unsrat, Manado. Penelitian berlangsung pada bulan Maret sampai dengan Juni 2011.

Penelitian mengunakan Metode Survel pada dua lokasi sampel di Kecamatan Kotamobagu Timur, yaitu Desa Kobo Besar dan Kobo Kecil. Masing-masing lokasi ditentukan tiga persemaian padi sawah yang digunakan sebagai tempat pengambilan sampel.

\section{Prosedur Kerja Survei}

Survei bertujuan untuk mengetahui dan menetapkan tempat sebagai lokasi penelitian. Kriteria lokasi penelitian ditentukan berdasarkan terdapatnya sekurang-kurang tiga areal persemaian padi.

\section{Pengambilan Sampel}

Pengambilan sampel dilakukan secara penyapuan dengan mengunakan jaring serangga. Masing-masing persemaian dilakukan penyapuan sebanyak 10 kali ayunan ganda dengan interval waktu seminggu sekali selama satu bulan. Serangga yang tertangkap dikoleksi di dalam botol beralkohol $70 \%$ kemudian dibawa ke laboratorium Entomologi dan Hama Tumbuhan, Fakultas Pertanian Unsrat untuk di identifikasi.

\section{Pengamatan}

Pengamatan serangga dilakukan di Laboratorium Hama dan Penyakit Tumbuhan. Fakultas Pertanian, Universitas Sam Ratulangi,
Manado. Serangga yang tertangkap di pisahkan berdasarkan jenis dan lokasi pengambilannya, kemudian diidentifikasi untuk mengetahui jenisnya.

\section{Indentifikasi}

Serangga-serangga yang ditemukan dikumpulkan dan disortir, kemudian dikoleksi di dalam botol koleksi yang telah berisi alkohol $70 \%$. Identifikasi dilakukan di Laboratorium Entomologi dan Hama Tumbuhan Fakultas Pertanian, Unsrat, Manado. Identifikasi serangga menggunakan kunci identifikasi serangga Ghauri (2009); Borror, D. J. C. Triplehorn, and N. F. Johnson (1989); Foltz (2001).

\section{HASIL DAN PEMBAHASAN}

Hasil penelitian menunjukkan bahwa, terdapat sepuluh jenis serangga yang berasosiasi pada per-semaian padi sawah di Kecamatan Kotamobagu Timur. Serangga-serangga yang ditemukan adalah Ordo Coleoptera, Orthoptera, Diptera, Odonata, Homoptera, dan Hymenoptera. Hasil identifikasi menunjukkan bahwa, seranggaserangga yang ditemukan pada areal persemaian padi adalah :

\section{Nepothettix spp.}

Serangga ini termasuk dalam Ordo Homoptera dan Famili Jassidae. Imago berwarna hijau (Gambar 1) dan terdapat bintik hitam pada bagian bawah kedua sayap depannya. Pada bagian ujung sayap depan terdapat nokta hitam. Serangga ini ditemukan pada pengambilan sampel ke 4 .

Sunihardi (2007) menyatakan bahwa Nepothettix spp. merupakan salah satu hama penting pada tanaman padi. Pentingnya Nepothettix spp sebagai perusak tanaman padi terletak pada akibat tusukannya yang dapat menyebarkan virus menyebabkan tanaman terserang virus tungro. Nepothettix spp selalu ditemukan pada daerahdaerah yang meliliki berbagai jenis umur tanaman. Wereng hijau yang baru menjadi dewasa berwarna kekuning-kuningan. Warna tersebut secara bertahap berubah menjadi hijau kekuning-kuningan yang akhirnya berubah menjadi hijau dalam waktu 3 jam. Imago jantan dan betina dapat hidup sampai 20 hari. Imago wereng hijau mempunyai tanda pada sayap bagian bawah yang lebih hitam dibanding dengan yang lain. 


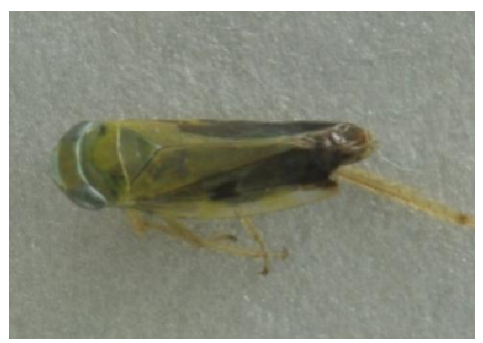

Gambar 1. Imago Nepothettix spp.

(Figure 1. Adult of Nepothettix spp)

Wereng hijau betina dapat menghasilkan telur sampai 300 butir. Produksi telur wereng hijau yang tertinggi terjadi pada suhu antara $29^{\circ}-33^{\circ} \mathrm{C}$. Pada suhu $20^{\circ} \mathrm{C}$ imago betina mati sebelum bertelur, sedangkan pada suhu $35^{\circ} \mathrm{C}$ produksi telur rata-rata rendah (Anonim, 2009; Anonim, 2010; Ghauri, 2009).

\section{Nilaparvata sp.}

Serangga ini termasuk dalam Ordo Homoptera dan Famili Delphacidae. Imago berwarna coklat kekuningan sampai coklat tua dan berukuran panjang 2-3,5 mm, (Gambar 2) mempunyai bintik-bintik coklat gelap pada sayap depannya. Tubuh berwarna coklat, dan sayap yang transparan, dengan venasi yang sangat jelas. Serangga ini ditemukan pada pengambilan sampel ke 4 .

Alamendah (2010), menyatakan bahwa Nilaparvata lugens atau disebut juga Wereng Coklat merupakan salah satu hama tanaman padi yang paling berbahaya dan sulit dibasmi. Bersama beberapa jenis wereng lainnya seperti wereng hijau (Nephotettix spp.) dan wereng punggung putih (Sogatella furcifera), wereng batang coklat telah banyak merugikan petani padi bahkan mengakibatkan puso dan gagal panen. Wereng batang coklat, menghisap cairan tumbuhan sehingga mengakibatkan perkembangan tumbuhan menjadi terganggu bahkan mati. Selain itu, wereng batang coklat (Nilaparvata lugens) juga menjadi vektor (organisme penyebar penyakit) bagi penularan sejumlah penyakit tumbuhan yang diakibatkan virus serta menyebabkan penyakit kerdil.

\section{Conocephalus sp.}

Serangga ini termasuk dalam Ordo Orthoptera Famili Tettigonidae. Tubuh berwarna kuning kecoklatan sayap hijau kehitaman dan berukuran panjang 16-22 mm (Gambar 3). Antena berbentuk philiform yang panjangnya melebihi ukuran tubuhnya; tungkai belakang berwarna kuning kecoklatan memiliki ukuran lebih besar dan panjang dari pada tungkai depan dan tengah, femur pada tungkai belakang bagian pangkalnya mengembang sedangkan tibia panjang dan memiliki duri-duri yang berwarna hitam rumus tarsi 3-3-3. Memiliki sayap belakang yang lebih panjang dari sayap depan. Serangga ini ditemukan pada pengambilan sampel ke 4 .

Conocephalus sp. adalah sejenis belalang yang berukuran kecil yang bersifat sebagai predator (Anonim, 2004). Aktifitas hidup Conocephalus sp. adalah predator terutama memangsa seranggaserangga kecil seperti kutu-kutuan pada habitatnya (Anonim, 2011).

Sunihardi (2007) menyatakan bahwa Conocephalus sp. sangat aktif di pagi hari, merupakan predator telur penggerek batang dan predator wereng coklat, wereng hijau, wereng zig-zag dan wereng punggung putih. Predator ini mempunyai panjang tubuh 25-32 mm dan mempunyai ciri khas antenanya 2-3 kali panjang tubuhnya dan tubuh berwarna hijau. Tempat hidupnya pada daun atau malai tanaman padi. Rentang hidup predator ini 110 hari dan jumlah telur yang dihasil-kan berkisar antara 15-30 butir/betina.

\section{Oxya sp.}

Serangga ini termasuk dalam Ordo Orthoptera Famili Acrididae. Imago berwarna kombinasi hijau dan coklat dan berukuran panjang antara 21-35 mm (Gambar 4). Pada bagian ventral berwarna hijau kekuningan dan pada tibia belakang berwarna biru keabu-abuan. Terdapat garis berwarna coklat tua kehitaman dari bagian faset sam- 
pai ke bagian dasar sayap. Serangga ini ditemukan pada pengambilan sampel ke-3 dan ke-4.

Pengamatan secara visual dijumpai serangga ini sedang memakan daun dengan meninggalkan gejala khas yaitu adanya bekas gigitan pada sebagian daun terutama pada bagian pinggir daun.

Kalshoven (1981) menyatakan bahwa serangga ini bersifat sebagai hama terutama menyerang bagian daun tanaman padi.

\section{Atherigona sp.}

Serangga ini termasuk dalam Ordo Diptera dan Family Muscidae. Bentuk imago hama ini menyerupai lalat rumah namun ukurannya yang agak lebih kecil (Gambar 5). Panjang tubuh kira-kira 2-3 $\mathrm{mm}$, thorax berwarna hijau abu-abu, abdomen mempunyai bintik kuning dan tungkai yang berwarna kuning. Serangga ini ditemukan pada pengambilan sampel ke 3 dan 4. Kalshoven (1981) menyatakan bahwa Atherigona sp. di Indonesia dikenal sebagai hama bibit padi. Hama ini terdapat pada hampir semua pertanaman padi di Indonesia.
Lalat bibit (Atherigona exigua) menyerang tanaman muda, akibat serangannya seringkali mematikan tanaman. Imago berwarna abu-abu, panjang 3-3,5 mm, punggungnya berwarna kuning kehijauan dengan tiga buah garis. Bagian abdomen berwarna coklat kekuningan (Anonim, 2011a).

\section{Ophionea sp.}

Ophionea sp. termasuk dalam Ordo Coleoptera Famili Carabidae. Imago berwarna coklat kehitaman, kepala berwarna hitam, toraks agak memanjang berwarna coklat, abdomen coklat kehitaman (Gambar 6), antena berwarna hitam terdiri dari 11 ruas ruas 1 , sampai ke-3 berwarna coklat kehitaman elytra lebih pendek dari sayap belakang sehingga tidak menutupi abdomen seutuhnya pada bagian tengah elytra berwarna coklat sedangkan pada bagian pangkal dan sebagian besar ujung berwarna hitam, tungkai agak panjang berwarna coklat kehitaman Rumus 4-4-4. Serangga ini ditemukan pada pengambilan sampel ke 4 .

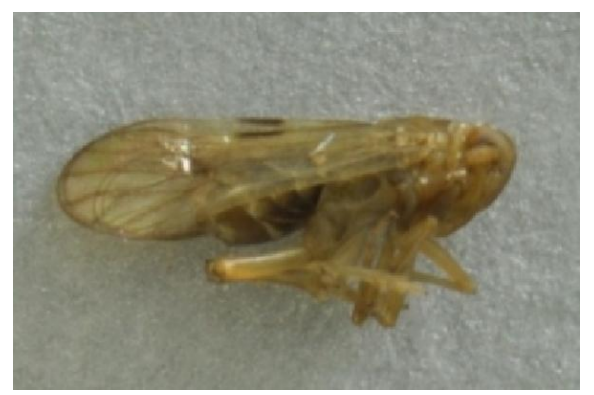

Gambar 2. Imago Nilaparvata sp.

(Figure 2. Adult of Nilaparvata sp.)

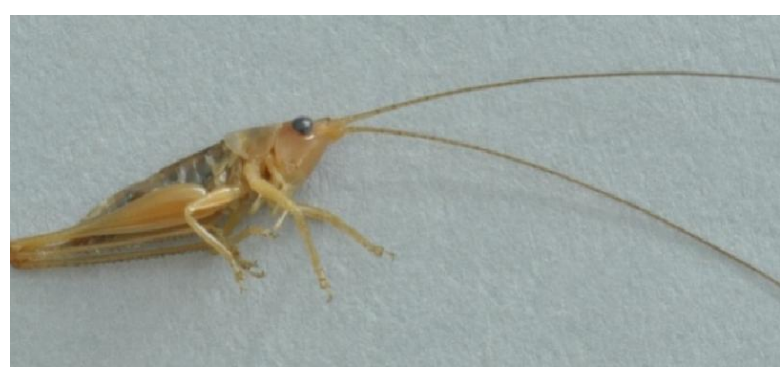

Gambar 3. Imago Conocephalus sp.

(Figure 3. Adult of Conocephalus sp.) 
Sunihardi (2007) melaporkan bahwa Ophionea sp. aktif mencari mangsa pada siang hari dan dapat berenang. Jenis mangsanya adalah wereng coklat, wereng hijau, hama putih, wereng zig-zag, wereng punggung puth, ulat bulu, ulat jengkal dan penggerek batang padi. Tempat hidupnya di pangkal batang atau di tanah yang tidak berair. Predator ini mempunyai ukuran panjang tubuh $8 \mathrm{~mm}$, tubuh mengkilat, kulit halus, kepala dan abdomen bagian tengah berwarna hitam kebiru-biruan. Siklus hidupnya 15 hari dan jumlah telur yang dihasilkan oleh seekor betina adalah 45 butir.

\section{Verania sp.}

Verania sp. termasuk dalam Ordo Coleoptera dan Famili Coccinelidae. Imago memiliki tubuh berbentuk kubah dan berwarna kuning kecoklatan (Gambar 7). Pada suture elytra berwarna coklat kehitaman membentuk garis lurus. Tungkai mempunyai Rumus 3-3-3. Serangga ini ditemukan pada pengambilan sampel ke-4.

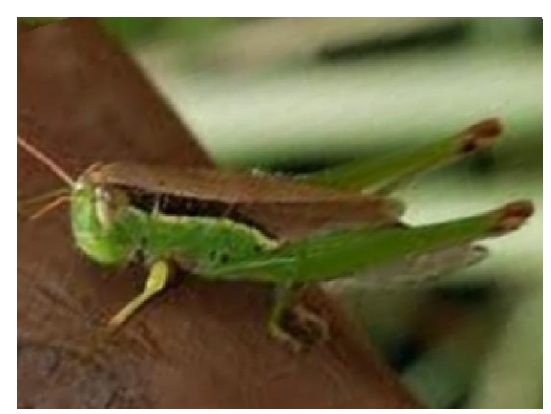

Gambar 4. Nimfa Nimfa Oxya sp.

(Figure 4. Nymphs of Oxya sp.)

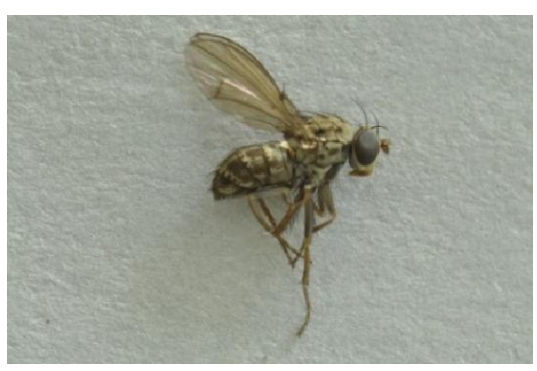

Gambar 5. Imago Atherigona sp.

(Figure 5. Adult of Atherigona sp.)

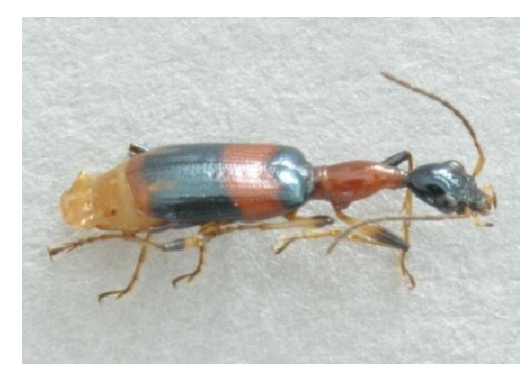

Gambar 6. Imago Ophionea sp.

(Figure 6. Adult of Ophionea sp.) 
Verania spp merupakan serangga yang banyak dijumpai pada tanaman pangan. Serangga ini bersifat polifag dan banyak terdapat di sekitar bunga padi dan jagung, namun banyak memakan serangga. Mangsa utama Verania spp adalah wereng batang dan wereng daun. Dilaporkan bahwa, siklus hidup Verania spp dari telur sampai dewasa ialah 29 hari. Lama hidup serangga ini berkisar antara 101,4-106,2 hari (Kartohardjono, 1988).

\section{Agriocnemis spp.}

Serangga ini termasuk dalam Ordo Odonata, Famili Coenagrionidae. Tubuh berbentuk ramping, mempunyai sepasang mata majemuk yang besar (Gambar 8). Abdomen menyerupai lidi berjumlah 9 ruas, ruas $1,2,3,8$, dan 9 berwarna biru muda. Toraks arah dorsal terlihat berwarna biru muda. Tungkai memiliki rambut-rambut yang menyerupai duri, tungkai umumnya berwarna kuning kecoklatan sedangkan pada sebagian femur berwarna coklat kehitaman. Serangga ini ditemukan pada pengambilan sampel ke 1, 2, 3, dan 4 .

Agriocemis sp. atau sering juga disebut capung kecil biasanya dijumpai di bawah tajuk tanaman dan bila hinggap pada batang tanaman tubuhnya mengarah lurus ke bawah. Capung ini merupakan predator wereng hijau, wereng coklat, wereng punggung putih dan hama putih palsu.

Predator ini mempunyai panjang tubuh 30 $\mathrm{mm}$, tubuhnya ramping berwarna merah oranye atau abu-abu kebiru-biruan dan sayapnya mempunyai bentuk jaringan yang rumit. Rentang hidupnya 10-30 hari dan jumlah telur yang dihasilkan oleh seekor betina adalah 30 butir (Sunihardi, 2007).

\section{Menochilus sp.}

Menochilus sp. termasuk dalam Ordo Coleoptera, Famili Coccinelidae. Imago berbentuk menyerupai kubah dan berukuran panjang 3-12 $\mathrm{mm}$. Pada bagian permukaan atas (dorsal) badan kumbang ini berwarna cerah kuning oranye (Gambar 9), kemerahan dengan bercak-bercak hitam, ada pula yang berwarna hitam dan permukaan bawah (ventral) badan rata dan pada umumnya berwarna pucat. Serangga ini ditemukan pada pengambilan sampel ke-3 dan ke-4.

Salah satu sifat yang jelas dari Coccinellidae adalah struktur sayapnya, kebanyakan kumbang mempunyai empat sayap, dengan pasangan sayap satu garis lurus di bawah pertengahan punggung dan menutupi sayap belakang. Sayap belakang berselaput tipis dan biasanya lebih panjang dari sayap depan dan apabila dalam keadaan istirahat bisanya terlipat di bawah sayap depan. Elitra secara normal hanya bertindak sebagai selubung pada pelindung. Sayap belakang, umumnya satu-satunya yang dipakai sebagai alat terbang (Anonim, 2003).

Serangga ini biasa di sebut kumbang predator warna kuning kecoklatan dan mempunyai becak hitam yang khas pada elitra. Menangkap mangsa bergerak lambat. Serangga ini mampu menghasilkan 150-200 turunan dalam 6-10 minggu. Dilaporkan bahwa daur hidup predator $M$. sexmaculatus berkisar antara 56 hingga 78 hari dengan rincian telur 4-5 hari, larva 20-25 hari, pupa 4-6 hari dan imago 28-42 hari. M. sexmaculatus mampu memangsa hama penting Bemisia tabaci dan Myzus persicae pada pertanaman cabai, sehingga secara hayati serangga predator $M$. Sexmaculatus sangat potensial untuk menekan penggunaan insektisida sintetis (Sunihardi, 2007).

\section{Famili Ichneumonidae}

Tubuh berwarna kuning kecoklatan. Antena panjang berbentuk filiform. Mata majemuk berwarna hitam. 3 pasang tungkai berwarna kuning kecoklatan. Tarsus berwarna coklat kehitaman 5-4-5. Kedua pasang sayap transparan dan ditumbuhi rambut-rambut halus. Serangga ini ditemukan pada pengambilan sampel ke 4 .

Dari sepuluh jenis serangga yang ditemukan di ekosistem persemaian padi ternyata terdiri dari berbagai peranan ekologis yaitu sebagian bersifat sebagai hama, predator dan parasitoid, seperti terlihat pada Tabel 1. 


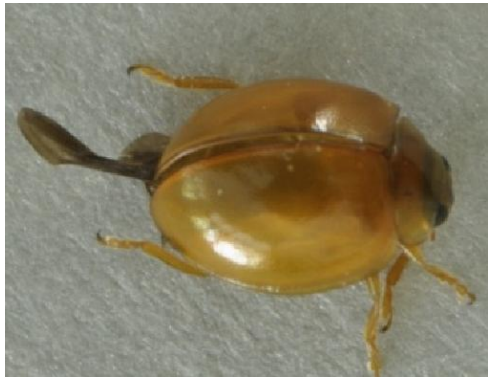

Gambar 7. Imago Verania sp.

(Figure 7. Adult of Verania sp.)

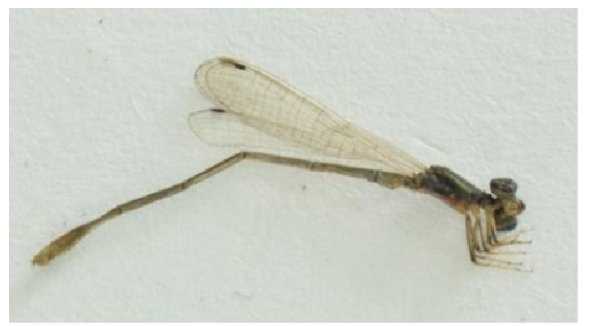

Gambar 8. Imago Agriocnemis spp.

(Figure 8. Adult of Agriocnemis spp.)

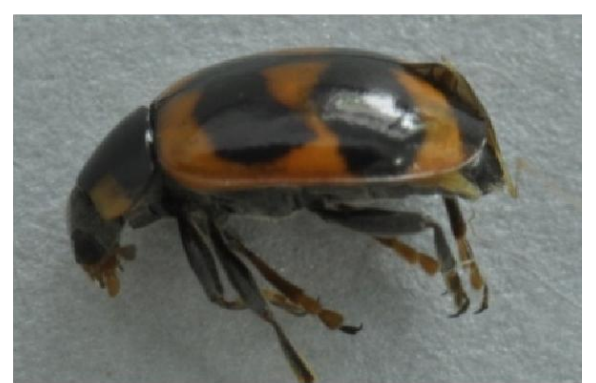

Gambar 9. Imago Menochilus sp.

(Figure 9. Adult of Menochilus sp.)

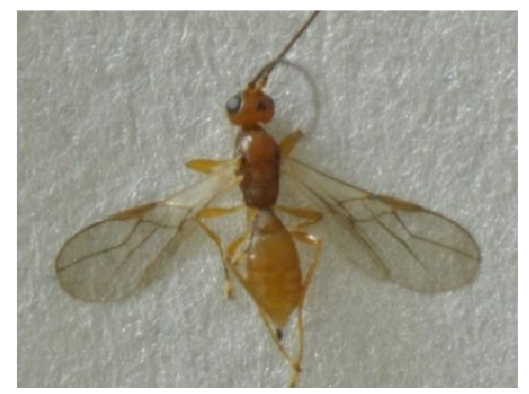

Gambar 10. Famili Ichneumonidae

(Figure10. Family Ichneumonidae) 
Melihat Tabel 1 ternyata serangga yang tertangkap pada penyapuan di areal persemaian terdiri dari empat jenis berperan sebagai hama, lima jenis berstatus predator, dan satu jenis berstatus parasitoid. Penentuan peranan ekologis serangga yang tertangkap tidak didasarkan pada pengamatan, tetapi berdasarkan pendekatan pada berbagai pustaka.

Ditemukannya hama Nephotettix spp. dan Nilaparvata sp. diduga karena pada areal disekitar persemaian terdapat tanaman padi berumur kirakira 2 bulan. Perani setempat belum menerapkan penanaman serempak, sehingga hama yang ada dapat berpindah ke areal pembibitan.

Hama wereng baik Nephotettix spp maupun Nilaparvata lugens merupakan jenis hama yang mengakibatkan kerusakan signifikan pada pertanaman padi sawah. Hama ini sangat sulit dikendalikan mengingat kemampuannya bermutasi sedemikian cepat dalam menyesuaikan diri terhadap lingkungan, khususnya tanaman padi sebagai sasarannya. Wereng coklat adalah hama yang mampu beradaptasi dengan berbagai lingkungan pada waktu yang cepat bahkan bisa menghasilkan populasi baru (biotipe) dalam waktu singkat. Wereng coklat juga mampu melemahkan kerja insektisida yang dianggap ampuh mengatasi hama ini sebelumnya. Dengan sifat- sifat yang dimilikinya, hingga tidak mudah untuk mengatasinya. Pola perkembangan hama ini bersifat biological clock, artinya wereng coklat dapat berkembang biak dan merusak tanaman padi disebabkan lingkungan yang cocok, baik pada musim hujan maupun musim kemarau. Penanaman padi yang terus menerus dengan menggunakan varietas yang sama dan memiliki gen tahan tunggal juga dituding dapat mempercepat timbulnya biotipe baru wereng coklat (Anonim, 2009).

Oxya sp. merupakan serangga hama yang memiliki kisaran inang yang luas. Hama ini memiliki tubuh yang berwarna kombinasi hijau, coklat, dan hitam serta berukuran lebih kecil dari belalang lainnya. Oxya sp. memakan daun tanaman yang dimulai dari pinggiran daun sehingga meninggalkan gejala yang khas (Anonim, 2010b).

Atherigona sp. merupakan salah satu hama penting pada tanaman padi. Di Indonesia hama ini dikenal sebagai hama lalat bibit. Telur berwarna putih, diletakkan tersebar pada bawah daun. Setelah 2-3 hari telur menetas. Larva yang baru keluar masuk ke dalam upih daun dengan bantuan air (embun). Kemudian masuk kedalam merusak titik tumbuh dan selanjutnya masuk sampai ke pangkal batang. Ulat hidup selama 8-18 hari. Kepompong berwarna kemerah-merahan, kemudian berubah menjadi agak gelap bila kepompongnya telah tua. Kepompong kadang-kadang dibentuk dalam jaringan tanaman, tapi umumnya dibentuk dalam tanah. Umur kepompong rata-rata 8 hari. Pada malam hari, larva menyebabkan serangan berat. Tanaman yang diserang kelihatan kerdil, berwarna kekuningan dan layu. Selain menyerang padi hama ini juga menyerang tanaman jagung (Anonim, 2011a; Kalshoven, 1981).

Serangga-serangga lainnya seperti Ophionea sp., Verania sp., Menochilus sp., Agriocnemis spp., Conocephalus sp. merupakan serangga predator dan hanya satu jenis yaitu spesies yang tergolong family Ichneumonida sebagai parasitoid.

Beberapa jenis serangga yang bersifat sebagai predator memiliki arti penting pada ekosistem tanaman padi karena dapat mengontrol perkembangan populasi serangga hama. Jenis serangga predator tersebut diantaranya Ophionea sp., Agriocnemis spp., dan Conocephalus sp. (Anonim, 2003).

Jenis serangga yang ditemukan pada berbagai tingkat umur tanaman di persemaian beragam dan terbanyak ditemukan pada tanaman berumur 3 dan 4 minggu, seperti terlihat pada Tabel 2. 
Tabel 1. Jenis Serangga dan Peranannya Pada Ekosistem Persemaian Padi Sawah di Kecamatan Kotamobagu Timur

(Table 1. Insects Type and its Role in the Ecosystem of Lowland Rice Nursery at sub-district of East Kotamobagu)

\begin{tabular}{llll}
\hline \multicolumn{1}{c}{ Ordo } & \multicolumn{1}{c}{ Jenis } & \multicolumn{2}{c}{ Keterangan } \\
\cline { 1 - 2 } Homoptera & \multicolumn{1}{c}{ Famili } & \multicolumn{1}{c}{ Genus/ spesies } & \\
\cline { 1 - 2 } Orthoptera & Jassidae & Nephotettix spp. & Hama \\
& Delphacidae & Nilaparvata sp & Hama \\
Coleoptera & Tettigonidae & Conocephalus sp. & Predator \\
& Acrididae & Oxya sp. & Hama \\
& Carabidae & Ophionea sp. & Predator \\
Diptera & Coccinelidae & Verania sp. & Predator \\
Odonata & Coccinelidae & Menochilus sp. & Predator \\
Hymenoptera & Muscidae & Atherigona sp. & Hama \\
\hline
\end{tabular}

Tabel 2. Jenis Serangga yang Ditemukan pada Berbagai Umur Tanaman Padi Sawah di Persemaian (Table 2. Types of Insects Found in a Variety Age of Lowland Rice Plant of Nursery)

\begin{tabular}{|c|c|c|c|c|}
\hline \multirow{2}{*}{ Jenis Serangga } & \multicolumn{4}{|c|}{ Umur Tanaman (minggu) } \\
\hline & 1 & 2 & 3 & 4 \\
\hline Nephotettix spp. (Homoptera; Jassidae) & & & & 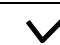 \\
\hline Nilaparvata lugens (Homoptera; Delphacidae) & & & & $\checkmark$ \\
\hline Conocephalus sp. (Orthoptera; Tettigonidae) & & & & \\
\hline Oxya sp. (Orthoptera; Acrididae) & & & $\checkmark$ & V \\
\hline Ophionea sp. (Coleoptera; Carabidae) & & & & $\checkmark$ \\
\hline Verania sp. (Coleoptera; Coccinelidae) & & & & $\checkmark$ \\
\hline Menochilus sp. (Coleoptera; Coccinelidae) & & & $V$ & $\checkmark$ \\
\hline Atherigona sp. (Diptera; Muscidae) & & & $\checkmark$ & $\checkmark$ \\
\hline Agriocnemis spp. (Odonata; Coenagrionidae) & $\vee$ & $\checkmark$ & $\checkmark$ & $v$ \\
\hline Ichneumonidae (Hymenoptera) & & & & $\checkmark$ \\
\hline
\end{tabular}

Keterangan : $\checkmark$ ditemukan

Melihat Tabel 2, ternyata kehadiran serangga pada ekosistem persemaian padi sawah tertinggi dijumpai pada pengambilan sampel ke-4 atau pada tanaman berumur 4 minggu. Hal ini menunjukkan bahwa keragaman jenis serangga dipengaruhi oleh umur dan atau lamanya tanaman berada pada suatu habitat.

Makin tinggi umur tanaman maka semakin lama tanaman tersebut berada dalam suatu habitat, sehingga kesempatan serangga mencari dan menemukan tanaman sebagai inangnya menjadi lebih besar.

Kogen (1985) menyatakan bahwa hubungan serangga dengan tanaman inang berlangsung melalui 5 tahap yaitu (1) tahap pengenalan habitat, (2) penemuan habitat, (3) pengenalan inang, (4) penemuan inang, dan (5) kesesuaian inang. Alatalat sensori seperti mata faset, antenna dan palpus sangat berperan dalam penemuan inang oleh serangga.

\section{KESIMPULAN DAN SARAN}

\section{Kesimpulan}

Serangga-serangga yang berasosiasi pada persemaian padi sawah di Kecamatan Kotamobagu Timur adalah tiga dari Ordo Coleoptera, dua dari Ordo Orthoptera, dua dari 
Ordo Homoptera dan masing-masing satu dari Ordo Diptera, Odonata dan Hymenoptera.

Serangg-serangga yang ditemukan dan berperan sebagai hama adalah Nephotettix sp. Nilaparvata sp., Oxya sp., dan Atherigona sp. Serangga-serangga yang berperan sebagai predator adalah Menochilus sp. dan Verania sp. Conocephalus sp., dan Ophionea sp.; dan sebagai parasitoid adalah Ichneumonidae.

Serangga yang tertangkap terbanyak pada pengambilan sampel ke-4 atau pada tanaman berumur 4 minggu.

Semakin meningkatnya umur bibit, meningkatkan keanekaragaman serangga.

\section{Saran}

Perlu dilakukan penelitian lanjutan untuk mengetahui populasi jenis hama pada persemaian.

\section{DAFTAR PUSTAKA}

Alamendah. 2010. Wereng Batang Coklat, Hama Padi yang Sulit Dibasmi. http://alamendah. wordpress.com/wereng.batang.coklat.ham a.padi.yang.sulit-dibasmi/.

Anonim. 2003. Mengatasi Hama dengan Kumbang dan Laba-laba. http://norlandoni.blogspot. com/2010/03/mengatasi-hama-dengankumbang-dan-laba.html

--------. 2004. Hama dan Penyakit Tanaman Padi. www.scribd.com/doc/Hama- dan-PenyakitTanaman-Padi.

-.--.-. 2007. Menanam Padi. Dinas Pertanian dan Kehutanan Kabupaten Bantul http://ngraho.com/2007/12/15/menanampadi/

--------. 2009. Wereng Hijau (Nephotettix virescens Distant). http://anafzhu.blogspot. com/2009/06/wereng-hijau-nephotettixvirescens.html.

--------. 2010. Pengendalian Hama Wereng. http://asbudisalamminds.blogspot.Com/20 10/08/pengendalian-hama-wereng.html. 2010b. Pengelolaan Tanaman Terpadu. http://id.shvoong.com/exact-sciences/ agronomy-agriculture/2059097pengelolaan-tanaman-terpadu-ptt-padi/. 2011. Conocephalus discolor From Wikipedia, the free encyclopedia. http://en. wikipedia.org/wiki/Conocephalus_discolor.

Anonim. 2011a. Lalat bibit (Atherigona exigua). http://moels.mywapblog.com/lalat-bibitatherigona-exigua.xhtml

Borror, D. J. C. Triplehorn, and N. F. Johnson. 1989. An Introduction To The Study of Insects. Sixth Edition. Saunders College Publishing, a devision of Holt, Rinehart and Winston, Inc.

Direktorat Bina Perlindungan Tanaman. 1990. Musuh alami Organisme Pengganggu Tanaman. Jakarta. Direktorat Jenderal Pertanian Tanaman Pangan

Foltz, J. L. 2001. Family 'entificationCoenegrionidae. University of Florida, Dept of Entomology and Nematology. eny3005.ifas.ufl.edu/lab1/odonata/ coenagroinadid.

Ghauri M. S. K. 2009. Revision of the genus Nephotettix Matsumura (Homoptera: Cicadelloidea Euscelidae) based on the type material. Bulletin of Entomological Research. 60: 481-512

Kalshoven, L. G. E. 1981. The Pest Of Crops In Indonesia. PT. Ichtiar Baru - van Hoeve. Jakarta.

Kartohardjono, A. 1988. Peran beberapa predator (laba-laba, Paederus sp, Ophionea sp., Cyrtorhinus sp. dan Coccinella..) Untuk mengurangi populasi wereng coklat (Nilaparvata lugens Stal.) Pada tanaman Padi. Balai Penelitian Tanaman Pangan Bogor.

Sunihardi. 2007. Petunjuk Teknis Pengendalian Penyakit Tungro Terpadu (Bagian 2) http://www.puslittan.bogor.net/index.php?b awaan=berita/fullteks_berita\&\&id_menu=3 \&id_submenu=14\&id=75. 
